\title{
腰仙椎，後側方固定法について
}

長崎大学整形外科

田島直也・河合尚志

田中宏和・瀬良敬 祐

国立嬉野病院

川村 勝 彦

長崎原爆病院

田口厚

\section{Posterolateral Lumbo-Scaral Fusion}

By

\section{N. Tajima, T. Kawai, H. Tanaka \& K. Sera \\ Department of Orthopedic Surgery Nagasaki \\ University, School of Medicine}

\section{K. Kawamura}

Ureshino National Hospital

\section{A. Taguchi}

Nagasaki Atomic Bomb Memorial Hospital

A consecutive series of 41 patients with unstable lumbo-sacral spine (spondylolysis, spondylolisthesis, disc lesion et al.) treated by a technique of posterolateral fusion resulted in a high percentage of good roentgenographic and clinical results.

Twenty-nine patients were male, and twelve were female (15-50 years).

The longest term follow-up was 3 years, and the shortest was ten months, the average being one year and six months.

Solid union occured in 90 per cent for fusion of single intervertebral joint roentgenographicly, but only 62 per cent for two or more levels.

However, a good clinical result was achieved in 83 per cent.

$$
\text { はじめに }
$$

腰椎分離症, 分離完り症などの構築上の欠陥と椎間 板狭少，偽汇り症などの退行性変性に基く腰椎不安定 椎に起因する腰痛症に対し, 保存的療法が有効でない 時に多くは脊椎固定術が行われている. 固定術式とし ては前方からと後方からの方法に二大別されるが，わ れわれは昭和 46 年以降, 主に後側方固定を行ってき て現在迄約 80 例に達した. 今回は術後 10 ケ月以上経 過し，且つ直接検診した 41 例に対し検討を加えたの で報告する。
症例

○性別, 年令

\begin{tabular}{|c|c|c|c|c|c|}
\hline 年令 & $10 \sim 20$ & $21 \sim 30$ & $31 \sim 40$ & $41 \sim 50$ 才 & 計 \\
\hline \begin{tabular}{c|c|c|c|c|} 
男子 \\
女子
\end{tabular} & 7 & 6 & 10 & 6 & 29 \\
& 1 & 5 & 6 & 12 \\
\hline 計 & 7 & 7 & 15 & 12 & 41 \\
\hline
\end{tabular}

男子 29 名, 女子 12 名, 最高 50 才, 最低 15 才

30 台, 40 台が多く全体の $2 / 3$ を占めている.

o follow-up 期間 
10 ケ月〜 3 年 (平均 1 年半)

○疾患 腰椎分離症

腰椎过り

14 例

13 例

disc lesion

spinal canal stenose

14 例

。再手術例 5 例 $\left(\begin{array}{c}\text { 以前受けた手術 } \\ \text { 前方固定 } 2 \text { 例 } \\ \text { 後方固定 } 3 \text { 例 }\end{array}\right)$

○椎弓切除併用したもの; 11 例

○平均手術時間 2 時間 40 分

○平均出血量 $950 \mathrm{cc}$

。術後合併症 $\begin{cases}\text { 皮膚罗死 } & 2 \text { 例 } \\ \text { 血清肝炎 } & 1 \text { 例 }\end{cases}$

\section{手術手技}

\section{侵入路について}

正中 J 型と奉椎傍側方の両者があるが，われわれは 神経根症状があり, 椎弓切除, 神経根の検索, ヘルニ ア摘出の必要がある時は正中 J 型侵入路を用いてい る．神経根症状がなく，固定だけを目的とする場合は 側方の Wiltse の paraspinal sacrospinalis splitting approach を始め用いていたが, 現在は殆んど全 例，正中 J 型侵入路で行なっている.

\section{骨移植について}

皮切後骨膜下にそって椎弓から軟部組織を剝離し， 開胸用の開創鈎を用い, 関節突起, 横突起先端迄露出 する. 横突起の後面, 基部, 関節突起側面も骨皮質を 削り，海綿骨組織を露出する．仙骨部は $1.5 \times 1.5 \mathrm{~cm}$ 大の溝をノミで作る．溝の先端は仙骨部の海綿骨内に 盲管様に少し入り込むようにする．関節突起から横突 起への侵入に際しては segmental artery に注意し電 気凝固を用い，止血を完全にする．採骨は同じ皮切で 腸骨翼から 1 椎間 $5 \times 1.5 \times 0.5 \mathrm{~cm}$ 大の移植骨 2 ケと 海綿骨をシャーレ 1/2 杯位とり，乙の海綿骨小片を移 植母床上と移植骨周囲のすきまに固くつめる．仙椎部 には溝の中に移植骨を叮き込む。

術後の固定

ギプスベッド 4 〜 週間，その後軟性コルセットを 約 4 ケ月装着しているが, ギプスベッド臥床期間は短 縮していいと考えている。

\section{成}

レ線成績

表 $1 レ$ 線 結 果

\begin{tabular}{|c|c|c|c|c|}
\hline & 例 & \multicolumn{2}{|c|}{ 瘞 } & 合 \\
\hline $\mathrm{L}_{5} / \mathrm{S}_{1}$ & 11 & $\begin{array}{l}\text { 可 } \\
\text { 不可 }\end{array}$ & & $\begin{array}{l}9 \\
2\end{array}$ \\
\hline $\mathrm{L}_{4} / \mathrm{L}_{5}$ & 11 & 可 & & 11 \\
\hline $\mathrm{L}_{4} \sim \mathrm{S}_{1}$ & 13 & $\begin{array}{l}\text { 可 } \\
\text { 不可 } \\
\text { " }\end{array}$ & $\begin{array}{l}\mathrm{L}_{4} / 5 \\
\mathrm{~L}_{5} / \mathrm{S}_{1}\end{array}$ & $\begin{array}{l}8 \\
4 \\
1\end{array}$ \\
\hline $\mathrm{L}_{3} \sim 5$ & 3 & $\begin{array}{l}\text { 可 } \\
\text { 不可 }\end{array}$ & & $\begin{array}{l}1 \\
2\end{array}$ \\
\hline $\mathrm{L}_{3} / 4$ & 1 & 可 & & 1 \\
\hline $\mathrm{L}_{3} \sim \mathrm{S}_{1}$ & 2 & $\begin{array}{l}\text { 可 } \\
\text { 不可 }\end{array}$ & & $\begin{array}{l}1 \\
1\end{array}$ \\
\hline
\end{tabular}

可 完全, 不可 不完全

前後, 斜方向, 側面中間位, 前後屈位の 6 枚のレ線 像で, 骨梁が連続し, 機能撮影で可動性がないものを 完全癒合と判定した。

成績は表 1 の如くで, $\mathrm{L}_{5} / \mathrm{S}_{1}$ 間と $\mathrm{L}_{4} / 5$ 間の各 1 椎 間固定では 22 例中 20 例 $(90 \%)$ が骨癒合良好であっ たが， $\mathrm{L}_{4} \sim \mathrm{S}_{1}$ 迄の 2 椎間固定 13 例では 2 椎間とも骨 癒合良好例は 8 例 $(62 \%)$ にすぎず, $\mathrm{L}_{4} / 5$ の偽関節 4 例, $\mathrm{L}_{5} / \mathrm{S}_{1}$ の偽関節 1 例であった。

\section{臨床成績}

河野の分類

優：愁訴が全く消失し, 重労働も出来るもの

良 : 術前の愁訴はないが，過学働でときに痛みがあ るもので普通には働いているもの

可：術前の愁訴は軽快し日常生活に支障はないが， 過労働が出来ないもの

不可：術前の愁訴は不変または増嚑し，日常生活に も支障をきたしているもの。

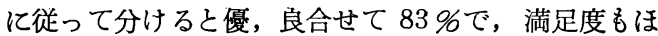
ぼ $93 \%$ 満足が得られている. 一方社会復帰の面で は原職復帰 31 例，職業変更が 7 例であるが，乙の中 には重労働から軽作業に変ったものの他, 家庭の事情 その他の理由での変更も含まれている.

(河野分類)

優

良

11 例)

可

不可
(満 足 度) $\left.\begin{array}{lr}\text { 満 } & 18 \text { 例 } \\ \text { まあ〜満足 } & 20 \text { 例 }\end{array}\right\} 93 \%$ 不満足 3 例 


$\begin{array}{lrr} & \text { (仕 } & \text { 事) } \\ \text { 原 職 復 帰 } & 31 \text { 例 } \\ \text { 職 業をか をた } & 7 \text { 例 } \\ \text { 仕事がよく出来ない } & 3 \text { 例 }\end{array}$

症例 $\mathrm{H}$ (写真 1 )

45 才, 工員, 術前著明な神経根症状ありヘルニア 摘出術々後側方固定術を同時に行った術後 2 年後のレ 線像で $\mathrm{L}_{4} / 5$ 瘜合良好, 現在原職復帰しいる. 河野の 分類では良。

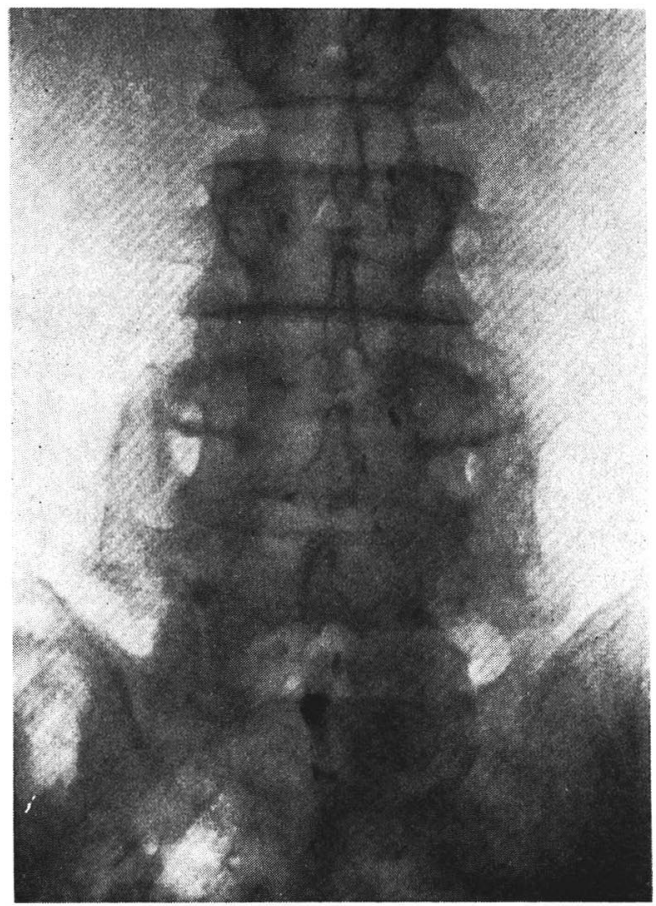

写真 1 症例 $\mathrm{H}$

\section{症例 Y (写真 2)}

32 才, 家婦, 不安定椎で $\mathrm{L}_{4} \sim \mathrm{S}_{1}$ 迄固定, 術後 1 年 10 ケ月のレ線像で骨癋合はほぼ良好であるが, 日常生 活で前屈障害を訴えている.

\section{症例 K(写真 3 )}

24 才男, 無職, 分離症で以前, 前方固定と後方固 定をうけたが, 䨐椎管狭唯と不安定椎の為, 椎弓切除 と後側方固定を行い, 術後 2 年のレ線像, レ線的には 骨瘾合はよいが，臨床的には腰部に重圧感があり，河 野の分類では可.

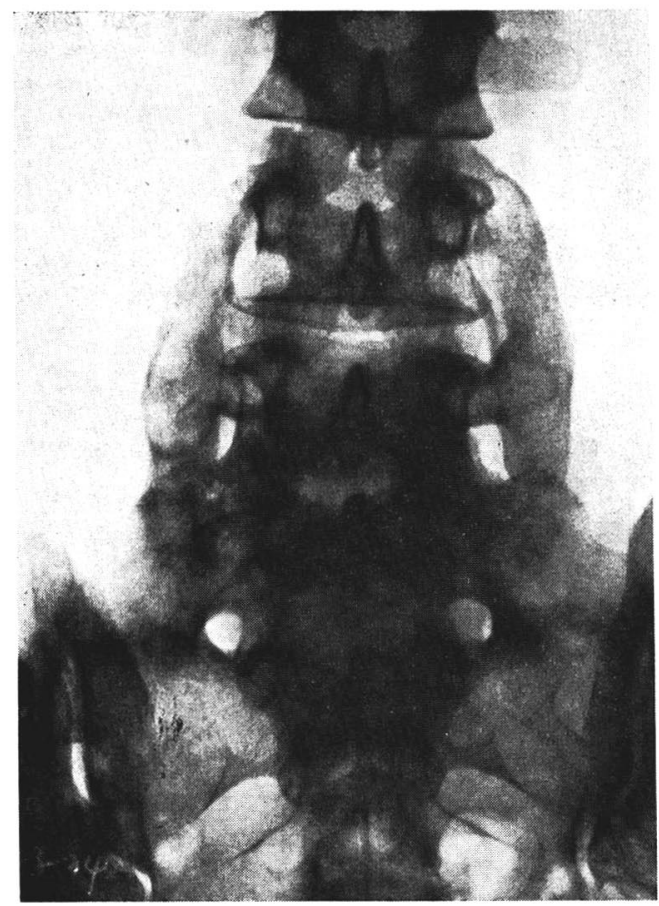

写真 2 症例 $Y$

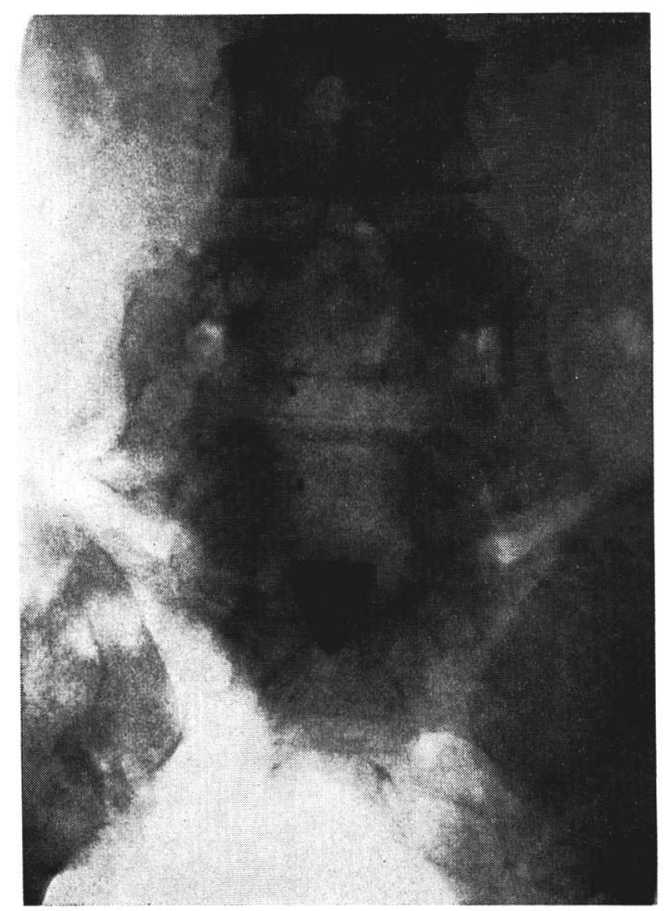

写真 3 症例 $\mathrm{K}$ 
考

按

1953, Watkins, M. B. が腰椎横突起間を固定する いわゆる posterolateral fusion を発表しその後の報 告で本法の優秀性が証明されている．手術手技などに 関してはそれぞれ多少の差異はあるが，本法は骨痹合 が良好なととが大きな特徴となっている.すなわち， 最初のWatkins は 28 人中 $68 \%$ 骨癒合であったが, Truchly, G. は 43 人中 $93 \%$, Adkins, E. W.は $83 \%$, Hoover, N. W. は 65 人中 $92 \%$, Stauffer, R. N. は 143 人中 $80 \%$ ，本邦でも添谷が 37 例中 95 \%, 戸際, 增原, 岩崎らはほぼ全例良好と発表してる.

ての骨癒合に関して(1)母床が豊富な血行に富む，(2) 傍脊椎筋群が移植骨を圧迫し固定力がよい, (3)横突起 周辺は脊椎運動の中心に近いため，セン断力の影響が 少いなどがあげられている. しかしRombold,C.は1 椎間では $96 \%$ \%゙あたのが， 2 椎間では $67 \%$ \%か骨 癒合がおこらなかったと報告しているが，われわれの 2 椎間固例でも， 2 椎間とも骨瘾合良好例は 13 例中 8 例で 1 椎間に比べ悪かった。これは各椎間に 1 ケづ つの移植骨を移植したため， $\mathrm{L}_{5}$ 横突起上で 2 ケの移 植骨の接触面積減少より 1 ケの骨片がズレたことも考 えられる. 岩崎らは $\mathrm{L}_{4} \sim \mathrm{S}_{1}$ 間は $7 \mathrm{~cm}$ の長さの移植 骨を用いているが, 过りがひどくて $\mathrm{L}_{4,5}$ の横突起と仙 椎の面が同一平面にない時には 1 ケの移植骨でしにく い解剖上の問題も関係してくる. また $\mathrm{L}_{4} / 5, \mathrm{~L}_{5} / \mathrm{S}_{1}$ 間 は腰椎では最大の生理的可動域を有する部位であるた め, ここの 2 椎間固定は正常運動パターンに対し影響 が大きい.すなわち下部腰椎 2 椎間固定に関しては手 術の適応, 手術術式, 術後の後療法について再検討の 必要があると思われる.

その他, 本法の有利な点として神経根, 脊髄の検索 が出来, $\mathrm{L}_{5} / \mathrm{S}_{1}$ の汇りが高度の例でも行うととが出来 るととがあげられる.

侵入路について Watkins, Wiltse，らは側方路， Adkins, Hoover らは正中路で行い, Wiltse は側方 路でもヘルニア摘出などは十分行えると述べている が, 将来, 万一椎弓切除などが可能であることや，外 観上からわれわれは正中路で行っている.

本法は手術時間が長く，手術侵襲も大きく出血量が 多いという不利な点があげられているが, 手術体位の 工夫, 手術法の進歩でかなり改善され，有利な面を考 え推奨出来る方法と思われる.
結語

昭和 46 年以降，後側方固定を約 80 例に行い，10ケ 月以上経過し，值接検診した 41 例につき中間成績を 報告した．骨痹合は 1 椎間の方が 2 椎間より良好で,

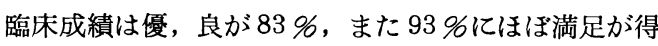
られた。

終りに御協力頂いた十善会病院, 山田先生, 国立佐 賀病院, 兼光先生, 佐世保綜合病院, 吉田先生, 国立 嬉野病院, 前田先生, 国立小浜病院, 諸岡先生に深謝 いたします。

\section{文献}

1) Adkins, E. W. O.: J. Bone \& Joint Surg. 37-B : 208-223, 1955.

2) Hoover, N. W.: J. Bone \& Joint Surg. 50A : 194-210, 1968.

3）岩崎洋明 - 他：日整会誌. 43：756-758, 1969.

4）增原健二・他：中部整災誌. $13 ： 863-865$, 1970.

5）三谷晋一・他: 手術. 25：452-459, 1971.

6) Peacock, H. K. : South. M. J. 57 : 1417-1420. 1964.

7) Rombold, C. : J. Bone \& Joint Surg. 48-A. 1282-1300, 1966.

8) Stauffer, R. N. eal.: J. Bone \& Joint Surg. 54-A, 1195-1204, 1972.

9) 高岸直人: 中部整災誌. $8: 625-627,1965$.

10）戸祭喜八・他：中部整災誌. $13 ： 196-198$, 1970.

11) Truchly, G.: J. Bone \& Joint Surg. 44-A : 505-512, 1962.

12）漆谷英礼 - 他：臨床整形. 9: 340-345, 1974.

13) Watkins, M. B. : J. Bone \& Joint Surg. 35A : 1014-1018, 1953.

\section{兵 問 国立鹿児島整形外科 今給黎尚実}

(1) 1 椎間分離症に対しての本法の適応は, 出血が 多いという点からして従来の固定法でも良いのではな いか.

(2) 術後の離床は何時, 行っているか.

\section{回答長崎大学 田島 直也 \\ (1) 出血量について}

平均 $950 \mathrm{cc}$ であるが，乙れには原疾患，麻酔体位 etc が関係している. 骨瘷合が従来のものよりよいの 


\title{
細胞診による軟骨性腫瘍の鑑別
}

$\begin{array}{ccccc}\text { 九州大学整形外科 } & & & & \\ \text { 緒 方 } & \text { 孝 } & \text { 俊・重 } & \text { 留 伸 一 } \\ \text { 平 } & \text { 宏 } & \text { 章・別 府 保 男 }\end{array}$

\section{Cytological Diagnosis of Caltilagious Tumors}

\section{By}

\author{
T. Ogata, S. Shigetome, H. Taira \& Y. Beppu
}

Department of Orthopedic Surgery (Director: Professor

A. Nishic), Faculty of Medicine, Kyushu University

14 cases of clatilagious bone tumor ( 5 enchondroma, a benign chondroblastoma, 3 chondromyxoid fibroma and 5 chondrosarcoma) were tried to differentiate by the cytological diagnostic procedure.

More than 15 smears per one cases were prepared, and at least 5 were stained by MayGrünwald and Giemsa's method which gave us the most reliable morphological picture. The residual smears were reserved for additional special stains, such as PAS, sudan III, alkaline phosphatase and acid phosphatase.

Besides morphological details, appreciatable items for the differential diagnosis among each tumors were 1) difference in staining intensity of materials, 2) grade of exfoliation of tumor cells, 3) extracellular substance, 4) cytoplasmic component, and 5) characteristic grouping of tumor cells.

Generally, non-epithelial tumor cell show variegated forms and some benign, caltilagious tumors such as chondromyxoid fibroma and benign chondroblastoma have mimic signs to cancer cells, but such tumors are rather easily distinguished from their own characteristic cytologic pictures.

\section{I. 緒言}

細胞竧の補助䛦断法としての有用性は, 子宮癌, 胃 癌, 乳癌などの治療においてすでに十分認められてい る. 整形外科領域においては Martin と Ellis ${ }^{1)}$ がは じめた aspiration biopsy と 1934 年にPool ${ }^{2)}$ らが発 表した流血中の瘤細胞の検出法との関連において細胞 診が論じられいる374). しかし上記の二方法ともに肝 腎の細胞採取率に難点があるために細胞診そのものの 持つ診断的価值の研究が十分に進められていない現況 である.

著者はてれまでに 200 例以上の非上皮性腫掦の細胞
診学的検索を組織学的検索と併行して行ってきた．細 胞形態の識別においては明らかに細胞診がすぐれて 居り, 組織診で常用する $\mathrm{H} \cdot \mathrm{E}$ 染色よりパパニコロー 染色, マイギームザ染色の方が色調の変化に富み, 視 覚的にもすぐれているととがわかった。

軟骨性腫瘍に限って細胞診学的に鑑別診断の可能性 を追求してみた.

\section{II. 検 索 症 例}

軟骨性腫瘍として, 内軟骨腫 5 例, 良性軟骨芽細胞 腫 1 例, 軟骨粘液線維腫 3 例, 軟骨肉腫 5 例を対象之 した（表一1）。 